\title{
APLIKASI PEMBAGIAN AIR IRIGASI PADA DAERAH IRIGASI SISTEM KEDUNG OMBO STUDI KASUS PADA BALAI PU SDA TARU SELUNA KUDUS
}

\author{
Sholihul Ibad \\ Fakultas Teknik, Program Studi Teknik Informatika \\ Universitas Muria Kudus \\ Email: sholihulibad80@gmail.com \\ Endang Supriyati \\ Fakultas Teknik, Program Studi Teknik Informatika \\ Universitas Muria Kudus \\ Email: endang.supriyati@umk.ac.id \\ Ahmad Abdul Chamid \\ Fakultas Teknik, Program Studi Teknik Informatika \\ Universitas Muria Kudus \\ Email: abdul.chamid@umk.ac.id
}

\begin{abstract}
ABSTRAK
Waduk kedung ombo yang terletak diperbatasan Kabupaten Grobogan, Sragen, dan Boyolali dimana separuh dari luas lahan tersebut diatas berada di Kabupaten Sragen, sampai saat ini masih tercatat sebagai waduk terbesar di Jawa Tengah yang dikelola oleh Balai Pekerjaan Umum Sumber Daya Air dan Penataan Ruang (PU SDA TARU) Seluna Kudus, mempunyai luas areal 4.600 ha. Dalam kondisi normal, waduk ini mampu menampung air sekitar 750 juta $\mathrm{m}^{3}$ sehingga mampu mengairi lahan seluas 63.624 hektar. Salah satu fungsi waduk kedung ombo adalah untuk pelayanan air irigasi yang mengairi wadukwaduk yang berada pada daerah layanan waduk kedung ombo, meliputi wilayah Kabupaten Grobogan, Demak dan Pati. Ketidakseimbangan antara ketersediaan air yang cenderung menurun dan kebutuhan air yang cenderung meningkat memerlukan usaha pengembangan sumber daya air yang berkelanjutan yang lebih efektif sedangkan daerah layanan waduk kedung ombo sendiri mencapai areal yang sangat luas, yang membutuhkan adanya pembagian air irigasi yang tepat baik dalam segi waktu maupun jumlah untuk memenuhi kebutuhan air irigasi yang mempengaruhi produksi tanam petani. Melihat dari pentingnya fungsi waduk kedung ombo tersebut, maka sangat perlu adanya sistem yang mengatur pembagian air irigasi pada waduk kedung ombo dengan tujuan sebagai bahan masukan dan pertimbangan kepada instansi terkait untuk pengambilan keputusan dalam perhitungan kebutuhan air dan pengaturan pembagian air irigasi ke waduk-waduk daerah layanan waduk kedung ombo sesuai kebutuhan.
\end{abstract}

Kata kunci: ketersediaan air, kebutuhan air, pengambilan keputusan.

\begin{abstract}
Kedung ombo dam located on the border of Grobogan, Sragen, and Boyolali District where half of the land area is located in Sragen regency, it is still recorded as the largest reservoir in Central Java managed by Balai Pekerjaan Umum Sumber Daya Air Dan Tata Ruang (PU SDA TARU) Seluna Kudus, has an area of 4,600 ha. Under normal conditions, this reservoir can hold water about 750 million $\mathrm{m} 3$ so it can irrigate 63,624 hectares of land. One of the functions of the dam kedung ombo is for irrigation water service which irrigates the reservoirs that are in the service area of kedung ombo dam, covering Grobogan, Demak and Pati districts. The imbalance between declining water availability and increasing water demand requires a more sustainable development of water resources while the Kedung ombo dam owns a vast area, requiring proper irrigation water distribution in both time and the amount to meet the irrigation water needs that affect farmers' crop production. Judging from the importance of the function of the dam kedung ombo, it is necessary to have a system that regulates the distribution of irrigation water in the dam kedung ombo with the purpose as input and consideration to the relevant institutions for decision making in the calculation of water requirements and arrangement of the distribution of irrigation water to the reservoirs service kedung ombo dam as needed.
\end{abstract}

Keywords: water availability, water demand, decision making. 


\section{PENDAHULUAN}

Waduk kedung ombo yang terletak diperbatasan Kabupaten Grobogan, Sragen, dan Boyolali dimana separuh dari luas lahan tersebut diatas berada di Kabupaten Sragen, sampai saat ini masih tercatat sebagai waduk terbesar di Jawa Tengah, mempunyai luas areal 4.600 ha. Dalam kondisi normal, waduk ini mampu menampung air sekitar 750 juta m3 sehingga mampu mengairi lahan seluas 63.624 hektar secara kontinu sepanjang tahun.

Waduk Kedung Ombo Jawa Tengah, selesai dibangun pada tahun 1989, merupakan waduk serbaguna dan telah beroperasi sejak tahun 1991. Yang dimaksud sebagai bendungan serbaguna yaitu waduk yang berfungsi untuk pengendalian banjir, PLTA, pelayanan irigasi, perikanan dan pariwisata. Gambar 1 merupakan daerah genangan waduk Kedung Ombo meliputi sebagian wilayah Kabupaten Grobogan, Boyolali, dan Sragen, serta daerah layanan waduk Kedung Ombo, meliputi wilayah Kabupaten Grobogan, Demak, Pati, dan sebagian kota Semarang.

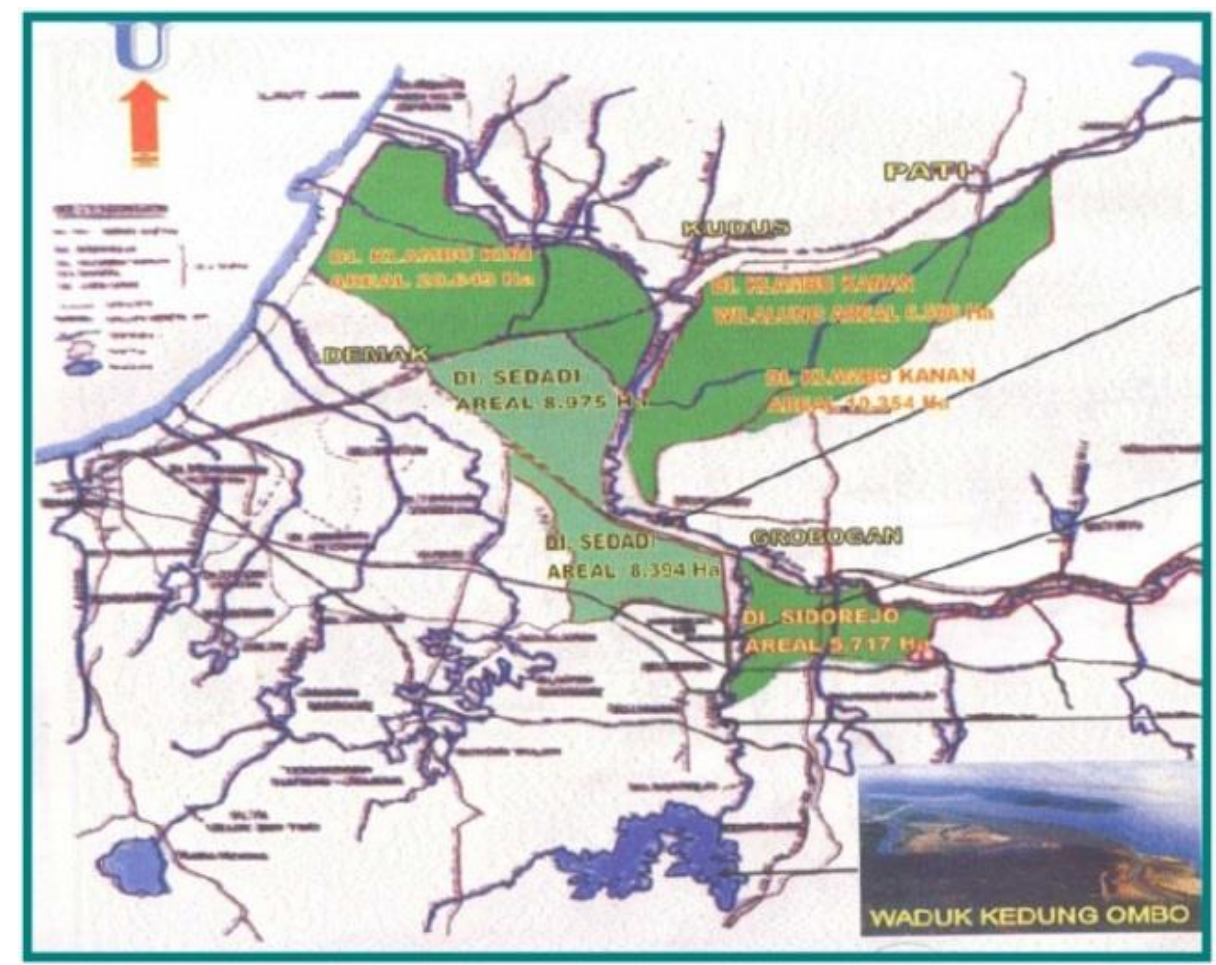

Gambar 1. Gambar Peta Wilayah Waduk Kedung Ombo

Ketidakseimbangan antara ketersediaan air yang cenderung menurun dan kebutuhan air yang cenderung meningkat memerlukan usaha pengembangan sumber daya air yang berkelanjutan yang lebih efektif sedangkan daerah layanan waduk kedung ombo sendiri mencapai areal yang sangat luas, yang membutuhkan adanya pembagian air irigasi yang tepat baik dalam segi waktu maupun jumlah untuk memenuhi kebutuhan air irigasi yang mempengaruhi produksi tanam petani.

Melihat dari pentingnya fungsi waduk kedung ombo tersebut, maka sangat perlu adanya sistem yang mengatur pengolahan angka pembagian air irigasi pada waduk kedung ombo dengan tujuan sebagai bahan masukan dan pertimbangan kepada instansi terkait untuk pengambilan keputusan dalam perhitungan kebutuhan air dan pengaturan pembagian air irigasi ke waduk-waduk daerah layanan waduk kedung ombo sesuai kebutuhan.

\section{METODE}

\subsection{Tempat Penelitian}

Lokasi penelitian ini dilakukan pada Balai PU SDA TARU Seluna Kudus. 


\subsection{Metode Pengumpulan Data}

Pengumpulan data dilakukan untuk memperoleh informasi yang dibutuhkan dalam rangka mencapai tujuan penelitian. Adapun teknik pengumpulan data yang dilakukan adalah sebagai berikut:

\subsubsection{Studi Lapangan}

Salah satu proses kegiatan untuk memperoleh data yaitu dengan cara terjun langsung ke lapangan, yaitu dengan melakukan kegiatan wawancara. Wawancara merupakan komunikasi dua arah untuk mendapatkan data dari responden. Penulis melakukan wawancara dengan pegawai Balai PU SDA TARU Seluna Kudus khususnya bidang operasi dan pemeliharaan (OP) secara langsung untuk mengumpulkan data dengan mengajukan sejumlah pertanyaan yang berkaitan dengan penelitian secara lisan. Bahan pertanyaan antara lain mengenai rumus-rumus yang dipakai untuk perhitungan kebutuhan air irigasi, realisasi tanam dan pemberian air (Faktor K).

\subsubsection{Studi Pustaka}

Studi Pustaka, mengumpulkan data dan informasi dengan cara membaca dan mempelajari bukubuku, referensi serta situs-situs penyedia layanan yang berhubungan dengan sistem pembagian air irigasi.

\subsubsection{Studi Dokumentasi}

Studi dokumentasi diambil dari balai PU SDA TARU Seluna Kudus untuk mendapatkan data-data terkait pembagian air irigasi sebagai bahan acuan pembuatan laporan skripsi dengan cara mempelajari dan mengamati serta menganalisis berkas-berkas atau dokumen-dokumen yang sudah ada yang berhubungan dengan masalah tersebut. Adapun dokumentasinya yaitu daftar realisasi dan rencana tanam serta kebutuhan air di waduk kedung ombo dalam bentuk excell.

\subsection{Metode Pengembangan Sistem}

Metode pengembangan sistem yang digunakan adalah dengan menggunakan model proses Waterfall yang dikemukakan oleh Pressman (2001). Tahap-tahap dalam model waterfall antara lain:

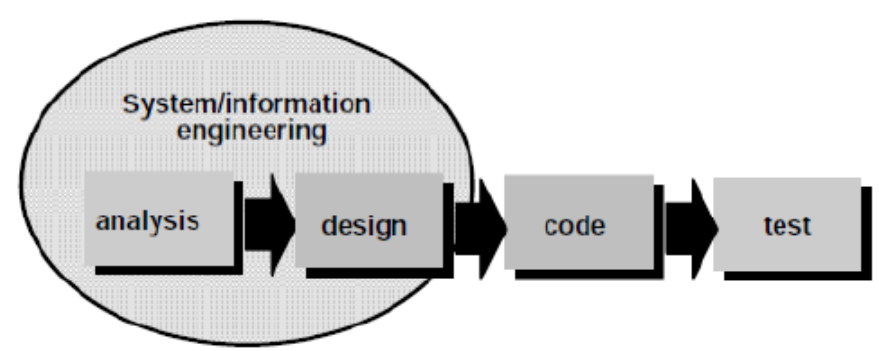

Gambar 2. Gambar Tahap-Tahap Model Waterfall

Berikut merupakan penjelasan dari gambar 2:

a. Analisis

Analisis merupakan tahap awal dimana dilakukan proses pengumpulan data dan identifikasi masalah mengenai pembagian air irigasi pada daerah irigasi waduk kedung ombo serta kebutuhan sistem yang difokuskan untuk pembuatan aplikasi

b. Desain

Melakukan perancangan agar dapat menyediakan rancangan yang diharapkan. Pada tahap ini dibuat Context Diagram, Data Flow Diagram (DFD), Entity Relational Diagram (ERD), perancangan database, perancang struktur tabel serta perancangan interface aplikasi.

c. Code (Pengkodean)

Melakukan penerapan hasil rancangan ke dalam bentuk yang dapat dibaca dan dimengerti oleh komputer.

d. Pengujian

Program yang dibuat harus di uji coba yang difokuskan pada aktifitas pemastian bahwa semua perintah yang ada telah dicoba agar bisa memastikan bahwa dengan masukan tertentu suatu 
fungsi akan menghasilkan keluaran sesuai dengan yang dikehendaki. Hal ini dilakukan untuk meminimalisir kesalahan.

\section{HASIL DAN PEMBAHASAN}

\subsection{Analisa Proses}

\subsubsection{Flowchart Diagram}

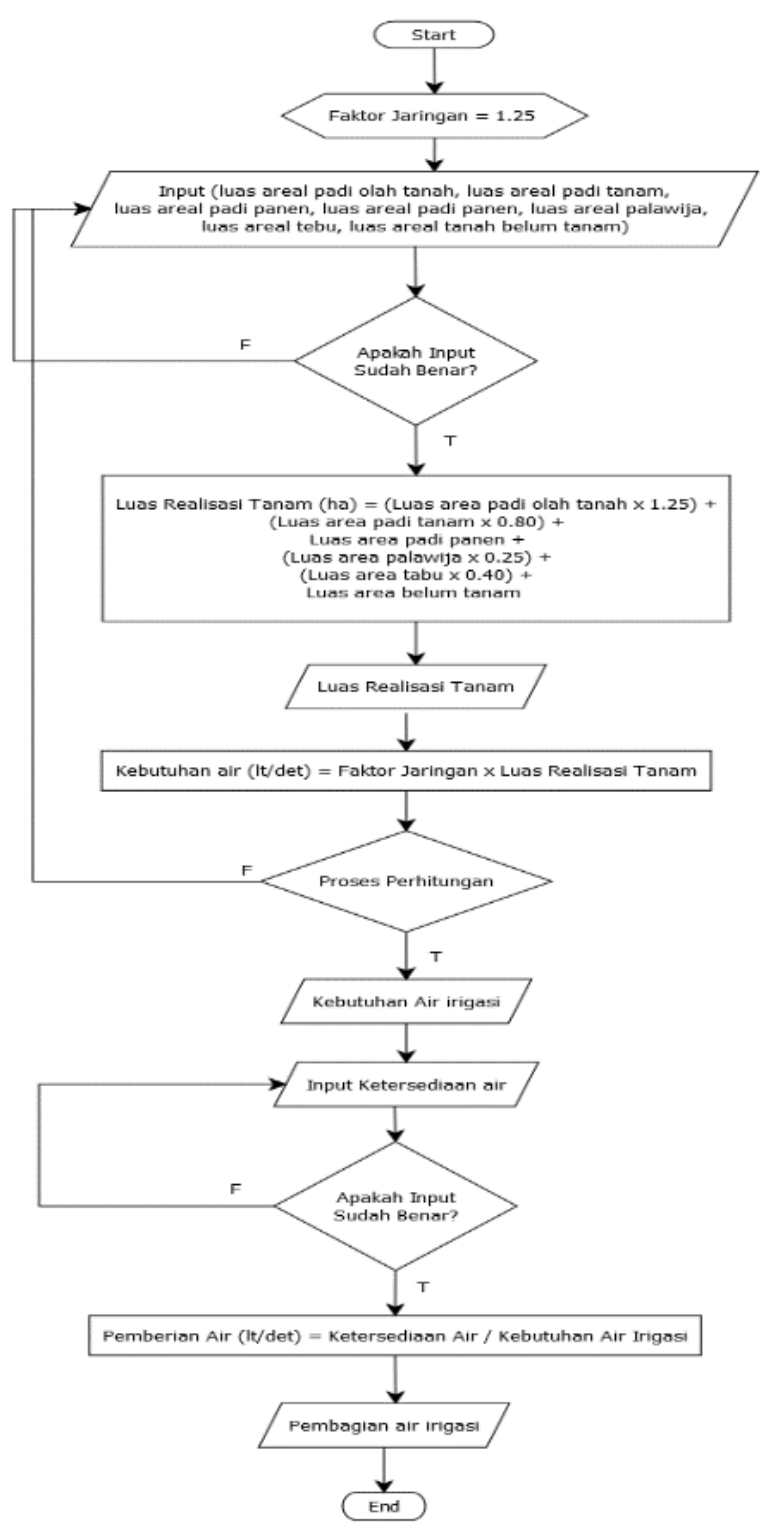

Gambar 3. Gambar Flowchat Diagram

Adapun Alur dari flowchart gambar 3 diatas adalah Petugas pilih start yang diwakili oleh simbol terminator yang menjabarkan kegiatan/tampilan form input luas areal padi olah tanah, luas areal padi tanam, luas areal padi panen, luas areal palawija, luas areal tebu dan luas areal tanah belum tanam, jika input BENAR (T) maka sistem akan menghitung secara otomatis luas ralisasi tanam, jika input SALAH (F) maka kembali ke proses input. Setelah mendapatkan luas realisasi tanam, petugas bisa menghitung besarnya kebutuhan air dengan perkalian faktor jaringan. Jika proses perhitungan BENAR (T) maka sistem akan menghitung secara otomatis kebutuhan air irigasi, jika SALAH (F) maka kembali ke proses input. Setelah mendapatkan besarnya kebutuhan air irigasi, petugas bisa menghitung besarnya pemberian air dengan menginputkan besarnya ketersediaan air irigasi. Jika proses penginputan data ketersediaan air 
BENAR (T) maka sistem akan menghitung secara otomatis pembagian air irigasi, jika SALAH (F) maka kembali ke proses input data ketersediaan air irigasi.

\subsubsection{Context Diagram}

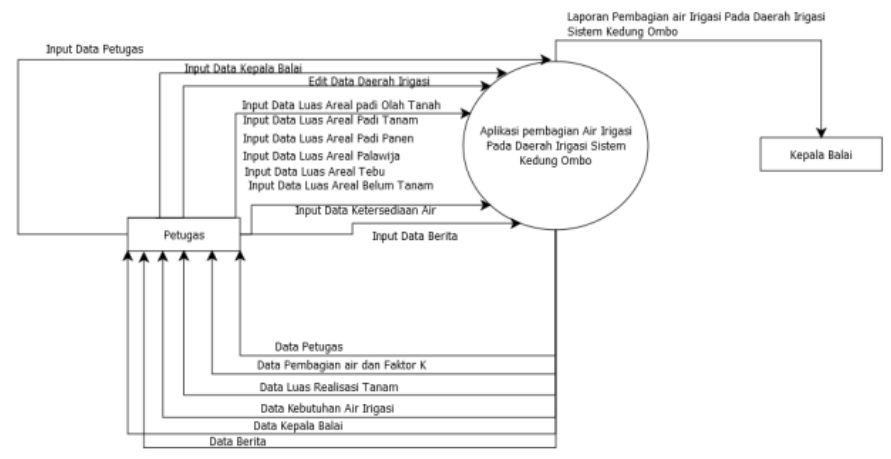

Gambar 4. Gambar Context Diagram

Adapun alur dari Context Diagram diatas adalah Petugas menginputkan data petugas, data kepala balai, edit daerah irigasi, data luas areal padi olah tanah, data luas areal padi tanam, data luas areal padi panen, data luas areal palawija, data luas areal tebu, data luas areal belum tanam, data ketersediaan air dan data berita. Sistem menyimpan data yang telah dinputkan oleh petugas pada database, kemudian pada entitas petugas sistem menampilkan data petugas, data pembagian air, data luas realisasi tanam, data kebutuhan air irigasi, data kepala balai dan data berita. Sedangkan pada entitas kepala balai digunakan untuk proses cetak laporan pembagian air irigasi pada daerah irigasi sistem kedung ombo.

\subsubsection{Data Flow Diagram (DFD)}

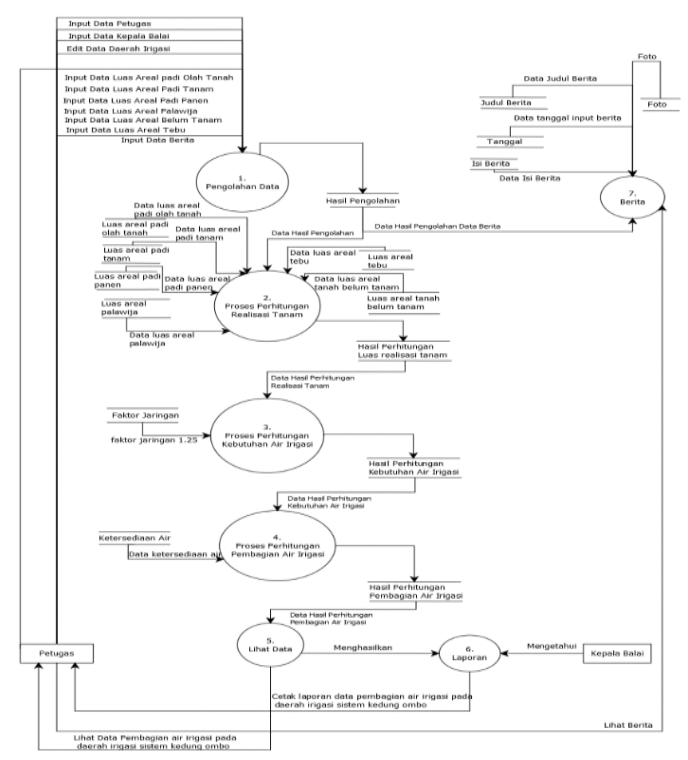

Gambar 5. Gambar DFD Level 0

Adapun alur dari DFD Level 0 di atas adalah Petugas menginputkan data petugas, data kepala balai, data daerah irigasi, data luas areal padi olah tanah, data luas areal padi tanam, data luas areal padi panen, data luas areal palawija, data luas areal tebu, data luas areal belum tanam, data ketersediaan air dan data berita. Data hasil pengolahan berita selanjutkan akan diproses pada tabel berita sedangkan data luas areal padi olah tanah, data luas areal padi tanam, data luas areal padi panen, data luas areal palawija, data luas areal tebu, data luas areal belum tanam digunakan untuk perhitungan realisasi tanam. Setelah mendapatkan luas realisasi tanam maka dilakukan proses perhitungan kebutuhan air irigasi dengan perkalian faktor jaringan 1.25. Setelah mendapatkan hasil kebutuhan air irigasi maka selanjutkan akan dilakukan proses perhitungan pembagian air irigasi dengan menginputkan data ketersediaan air. Setelah mendapatkan pembagian air maka bisa dilihat data tersebut dan akan menghasilkan sebuah laporan yang diketahui oleh kepala balai. 


\subsubsection{Entity Relationship Diagram (ERD)}

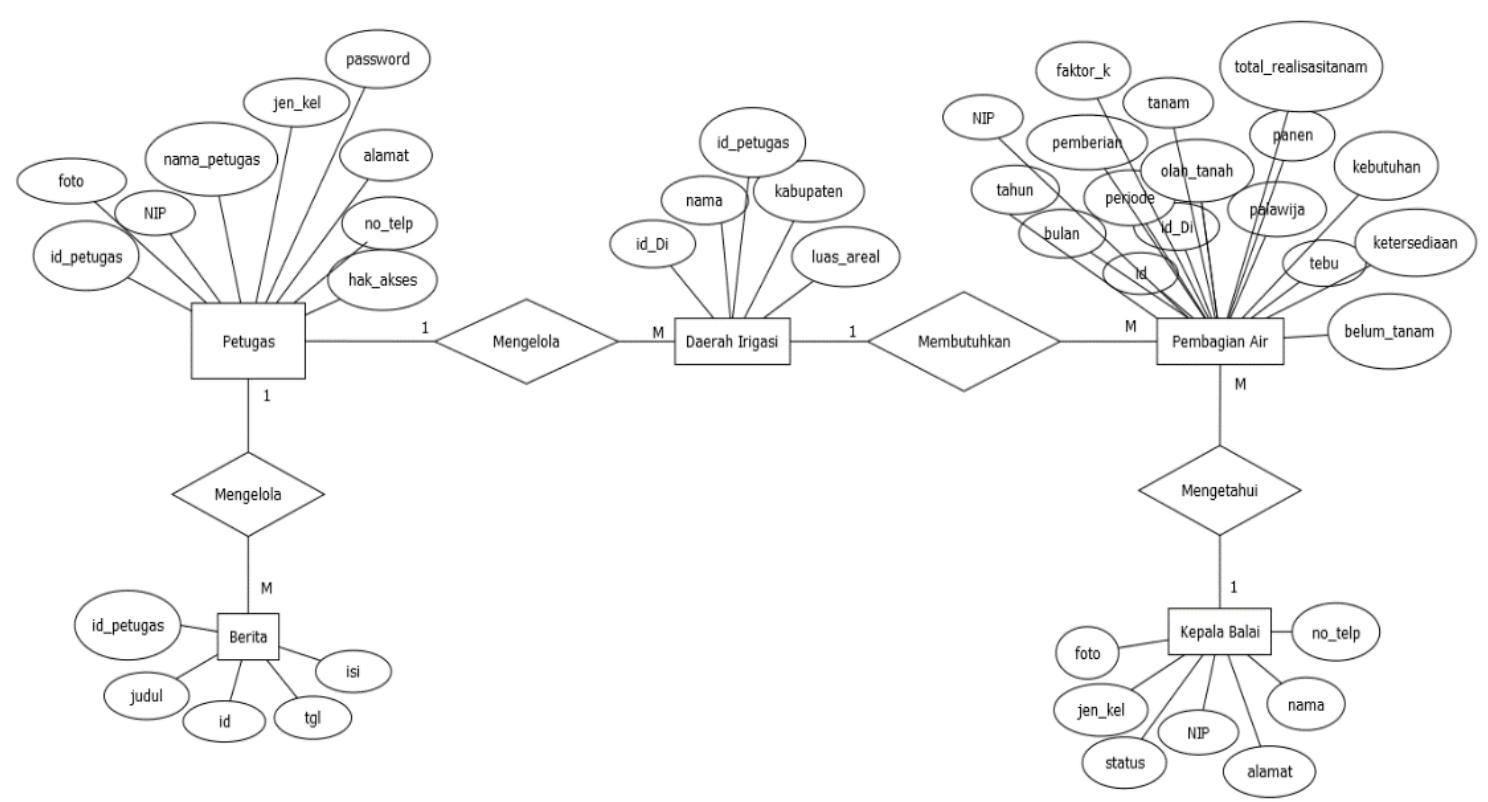

Gambar 6. Gambar ERD

Pada gambar 6 di atas dapat dilihat bahwa tabel petugas yang memiliki atribut id_petugas, NIP, nama_petugas, foto, jen_kel, alamat, no_telp, password dan hak_akses dimana id_petugas sebagai Primary Key memiliki relasi dengan tabel daerah irigasi yang mempunyai attribut id_Di, id_petugas, nama, kabupaten dan luas_areal dimana id_Di sebagai Primary Key dan id_petugas sebagi Foreign Key. Pada tabel petugas dan daerah irigasi memiliki relasi one to many, pada tabel petugas memiliki relasi dengan tabel berita yang mempunyai attribute id, id_petugas, tgl, judul, foto dan isi dimana id sebagai Primary Key dan id_petugas sebagi Foreign Key. Pada tabel petugas dan berita memiliki relasi one to many serta pada tabel daerah irigasi memiliki relasi dengan tabel pembagian air yang mempunyai attribut id, periode, bulan, tahun, NIP, id_Di, olah tanah, tanam, panen, palawija, tebu, belum_tanam, total_realisasitanam, kebutuhan, ketersediaan, pemberian dan faktor_k dimana id sebagai Primary Key, id_Di sebagi Foreign Key dan NIP kepala balai sebagi Foreign Key. Pada tabel daerah irigasi dan pembagian air memiliki relasi one to many, pada tabel pembagian air memiliki relasi dengan tabel kepala balai khususnya untuk cetak laporan yang mempunyai attribut NIP, nama, foto, jen_kel, alamat, no_telp dan status dimana NIP sebagai Primary Key. Pada tabel kepala balai dan pembagian air memiliki relasi one to many.

\subsection{Hasil Analisa}

Data yang digunakan untuk pembagian air irigasi ini diambil dari daftar realisasi dan rencana tanam serta kebutuhan air di waduk kedung ombo dalam bentuk excell. Sebagai contoh perhitunganya secara manual diambil kasus pada periode II bulan september tahun 2017, data bisa dilihat pada tabel 1 . 
Tabel 1. Tabel hasil analisa pembagian air irigasi pada daerah irigasi sistem kedung ombo periode II bulan September 2017

\begin{tabular}{|c|c|c|c|c|c|c|c|c|c|c|c|c|c|}
\hline \multirow[b]{2}{*}{ NO. } & \multirow[b]{2}{*}{ DAERAH IRIGASI } & \multirow[b]{2}{*}{ KABUPATEN } & \multirow{2}{*}{$\begin{array}{c}\text { LUAS } \\
\text { AREAL } \\
\text { BAKU } \\
(H A)\end{array}$} & \multirow[b]{2}{*}{$\begin{array}{c}\text { OLAH } \\
\text { TANAH }\end{array}$} & \multirow[b]{2}{*}{$\begin{array}{c}\text { PADI } \\
\text { TANAM }\end{array}$} & \multicolumn{3}{|c|}{ REALISASI TANAM } & \multirow[b]{2}{*}{$\begin{array}{l}\text { BELUM } \\
\text { TANAM }\end{array}$} & \multirow[b]{2}{*}{$\begin{array}{c}\text { JUMLAH } \\
(\boldsymbol{H a})\end{array}$} & \multicolumn{2}{|c|}{$\begin{array}{c}\text { REALISASI PEMBERIAN AIR } \\
\text { (lt/det) }\end{array}$} & \multirow[b]{2}{*}{ FAKTOR $K$} \\
\hline & & & & & & PANEN & PALAWIJA & $T E B U$ & & & KEBUTUHAN & PEMBERIAN & \\
\hline 1 & Sidorejo + Lanang & Grobogan & 7.938 & 1.000 & 2.000 & 3.000 & 4.000 & 5.000 & 6.000 & 14.850 & 18.563 & 37.710 & 1.000 \\
\hline 2 & Sidorejo & Grobogan & 6.038 & 9.000 & 4.000 & 7.000 & - & 5.000 & 1.000 & 24.450 & 30.563 & 17.996 & 1.000 \\
\hline 3 & Sidorejo Kiri/Lanang & Grobogan & 1.900 & 5.800 & 6.000 & 2.000 & 4.000 & - & 3.000 & 18.050 & 22.563 & 0.310 & 0.310 \\
\hline 4 & Sedadi & Grobogan & 8.975 & 4.000 & 3.400 & 2.000 & 4.700 & 3.800 & 4.000 & 16.415 & 20.519 & 31.678 & 1.000 \\
\hline 5 & Sedadi & Demak & 7.080 & 3.500 & 6.900 & - & 1.000 & 2.000 & 4.000 & 14.945 & 18.681 & 37.471 & 1.000 \\
\hline 6 & Klambu Kanan & Kudus & 1.006 & 2.000 & 3.000 & 4.000 & 2.000 & 5.000 & 7.000 & 18.400 & 23.000 & 30.435 & 1.000 \\
\hline 7 & Klambu Kanan & Pati & 8.238 & 1.000 & 5.000 & 7.000 & - & - & 8.000 & 20.250 & 25.313 & 1.975 & 1.000 \\
\hline 8 & Klambu Kanan & Grobogan & 104.000 & 3.400 & 3.000 & 2.000 & 4.000 & 6.000 & 8.000 & 20.050 & 25.063 & 27.930 & 1.000 \\
\hline 9 & Klambu Wilalung & Grobogan & 775.000 & - & - & 3.000 & 4.800 & 4.500 & 4.000 & 10.000 & 12.500 & 56.000 & 1.000 \\
\hline 10 & Klambu Wilalung & Kudus & 5.262 & 1.450 & 2.000 & 5.000 & 7.000 & 7.000 & 5.000 & 17.963 & 22.453 & 31.176 & 1.000 \\
\hline 11 & Klambu Wilalung & Pati & 4.780 & 6.000 & 6.000 & 4.000 & 6.700 & 4.300 & 2.400 & 22.095 & 27.619 & 25.345 & 1.000 \\
\hline \multirow[t]{2}{*}{12} & Klambu Kiri & Demak & 21.588 & 3.400 & 5.000 & 6.900 & 4.670 & 3.500 & 4.000 & 21.718 & 27.147 & 25.786 & 1.000 \\
\hline & & & & JUMLAH & & & & & & 219 & 274 & 324 & \\
\hline
\end{tabular}




\subsection{Rancangan Tabel Database}

\subsubsection{Tabel Petugas}

Tabel 2. Tabel petugas

\begin{tabular}{|c|c|c|c|}
\hline No & Nama field & Type & Width \\
\hline 1 & id_petugas $(\mathrm{PK})$ & Varchar & 11 \\
\hline 2 & NIP & Int & 20 \\
\hline 3 & nama_petugas & Varchar & 60 \\
\hline 4 & Alamat & Text & \\
\hline 5 & jen_kel & Varchar & 10 \\
\hline 6 & no_telp & Varchar & 12 \\
\hline 7 & Foto & Varchar & 25 \\
\hline 8 & Password & Varchar & 20 \\
\hline 9 & hak_akses & Varchar & 11 \\
\hline 10 & Status & Varchar & 11 \\
\hline
\end{tabular}

\subsubsection{Tabel Kepala Balai}

Tabel 3. Tabel kepala balai

\begin{tabular}{clcc}
\hline No & \multicolumn{1}{c}{ Nama field } & Type & Width \\
\hline 1 & NIP (PK) & int & 20 \\
2 & Nama & varchar & 60 \\
3 & Foto & varchar & 25 \\
4 & jen_kel & varchar & 12 \\
5 & alamat & text & \\
6 & no_telp & varchar & 12 \\
7 & status & varchar & 10 \\
\hline
\end{tabular}

\subsubsection{Tabel Daerah Irigasi}

Tabel 4. Tabel daerah irigasi

\begin{tabular}{cccc}
\hline No & Nama field & Type & Width \\
\hline 1 & Id_Di (PK) & varchar & 50 \\
2 & id_petugas (FK) & varchar & 11 \\
3 & Nama & varchar & 50 \\
4 & Kabupaten & varchar & 50 \\
5 & luas_areal & float & \\
\hline
\end{tabular}




\subsubsection{Tabel Data Pembagian Air Irigasi}

Tabel 5. Tabel pembagian air irigasi

\begin{tabular}{|c|c|c|c|}
\hline No & Nama field & Type & Width \\
\hline 1 & Id (PK) & Int & 11 \\
\hline 2 & Periode & varchar & 5 \\
\hline 3 & Bulan & varchar & 50 \\
\hline 4 & Tahun & varchar & 25 \\
\hline 5 & id_Di (FK) & varchar & 50 \\
\hline 6 & NIP (FK) & varchar & 20 \\
\hline 7 & olah_tanah & float & \\
\hline 8 & Tanam & float & \\
\hline 9 & Panen & float & \\
\hline 10 & Palawija & float & \\
\hline 11 & Tebu & float & \\
\hline 12 & belum_tanam & float & \\
\hline 13 & total_realisasitanam & float & \\
\hline 14 & Kebutuhan & float & \\
\hline 15 & Ketersediaan & float & \\
\hline 16 & Pemberian & float & \\
\hline 17 & faktor_k & float & \\
\hline
\end{tabular}

\subsubsection{Tabel Berita}

Tabel 6. Tabel Berita

\begin{tabular}{cccc}
\hline No & Nama field & Type & Width \\
\hline 1 & Id (PK) & Int & 11 \\
2 & id_petugas (FK) & varchar & 11 \\
2 & Tgl & date & \\
3 & Judul & varchar & 100 \\
4 & Foto & varchar & 25 \\
5 & Isi & text & \\
\hline
\end{tabular}




\subsubsection{Relasi Antar Tabel}

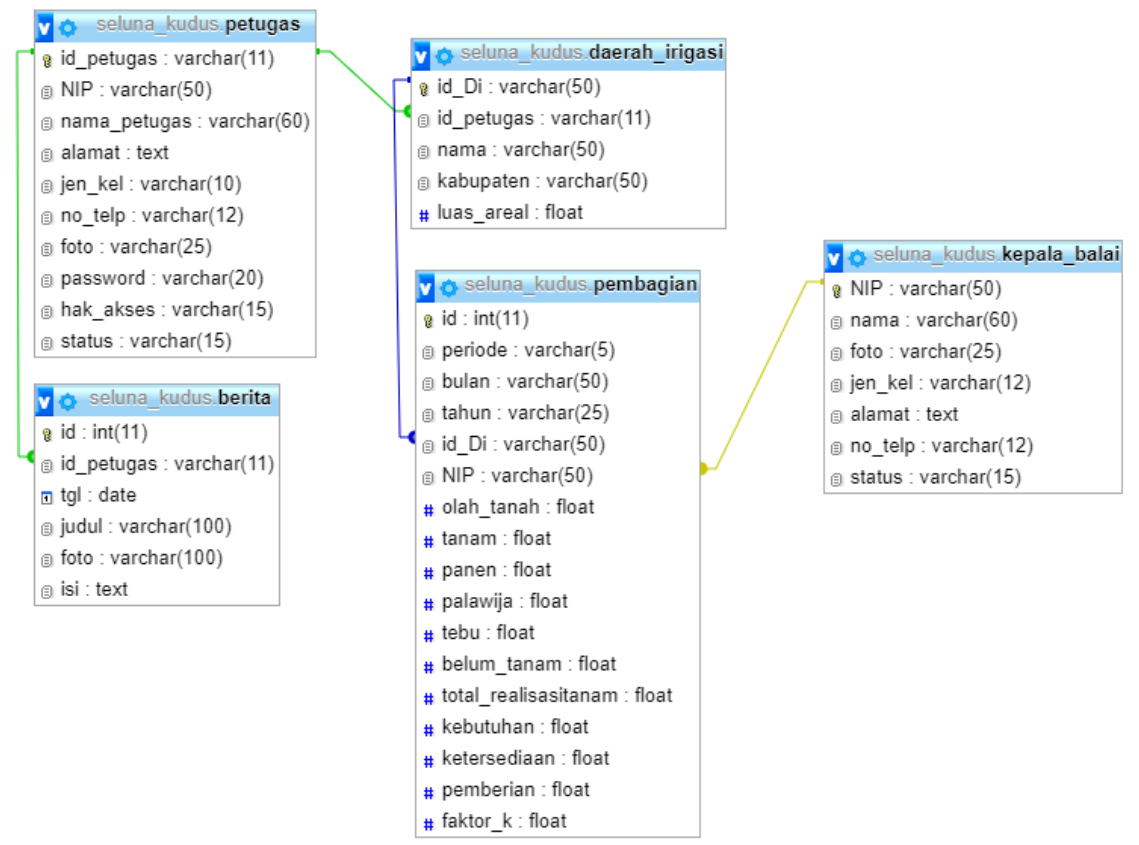

Gambar 7. Gambar Relasi Antar Tabel

\subsection{Halaman Struktur Menu}

\subsubsection{Halaman Admin}

Pada halaman utama admin, petugas biasa mengakses menu data daerah irigasi, data pembagian air irigasi, data petugas, data kepala balai, data berita, dan cetak laporan. Untuk lebih jelasnya bisa dilihat pada gambar 8 .

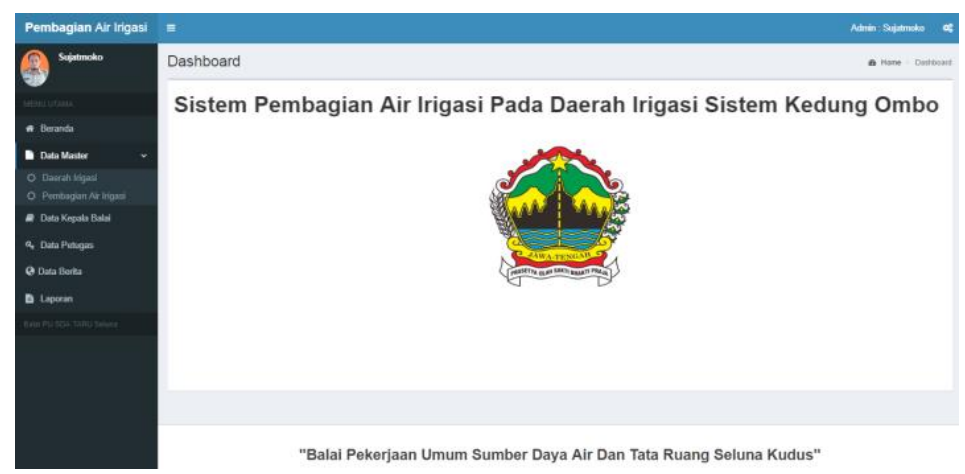

\section{Gambar 8. Gambar Halaman Utama Admin}

Adapun penjelasan dari gambar 8:

a. Menu Daerah Irigasi

Menu daerah irigasi digunakan untuk view data daerah irigasi yang dialiri oleh waduk kedungombo. Lihat pada gambar 9. 


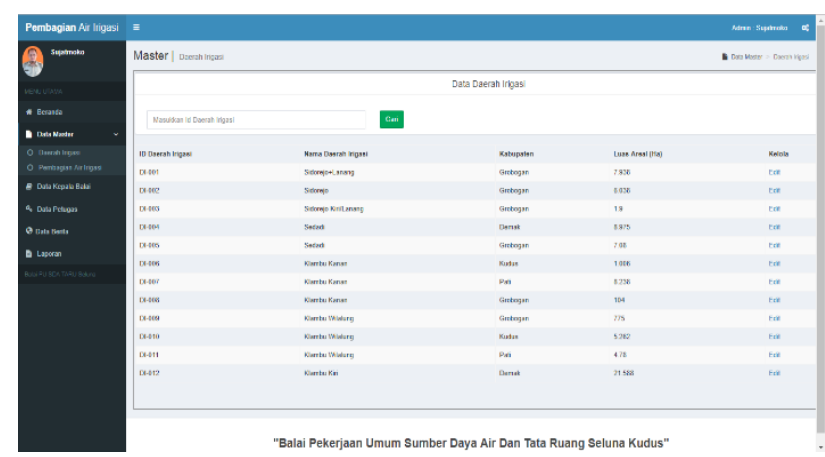

Gambar 9. Gambar Menu Daerah Irigasi

Pada Menu daerah irigasi tidak terdapat menu untuk tambah daerah irigasi karena data daerah irigasi sudah ditetapkan oleh Balai PU SDA TARU Seluna Kudus. Hanya terdapat menu edit untuk mengganti jika nama daerah irigasi, kabupaten atau luas areal salah, menu edit dapat dilihat pada gambar 10 .

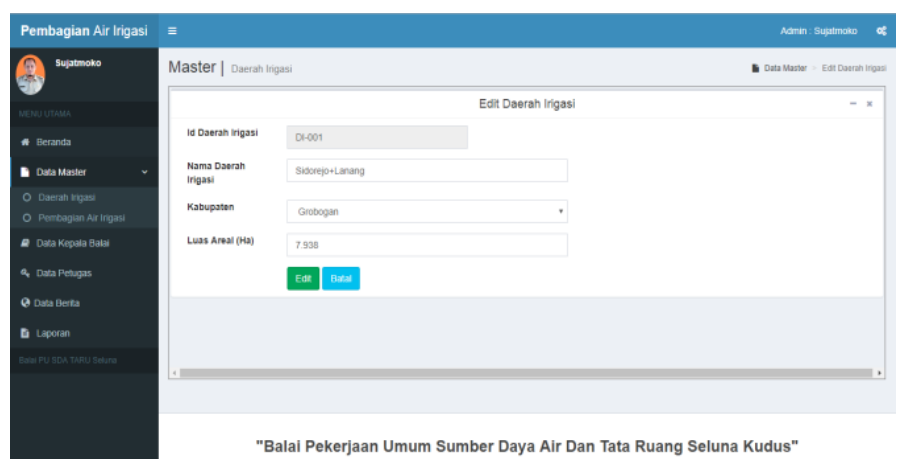

\section{Gambar 10. Gambar Menu Edit Daerah Irigasi}

b. Menu Pembagian Air Irigasi

Menu pembagian air irigasi digunakan untuk view data pembagian air irigasi. Lihat pada gambar 11.

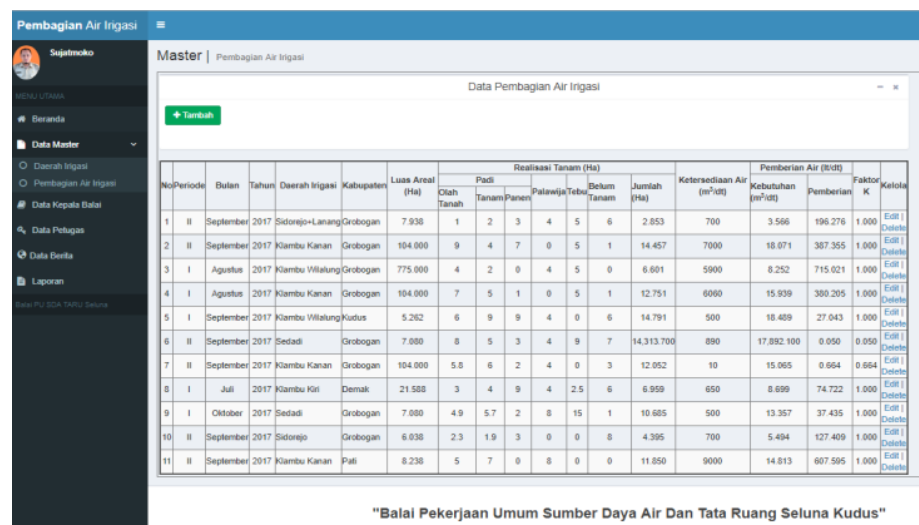

Gambar 11. Gambar Menu Pembagian Air Irigasi

Pada menu pembagian air irigasi terdapat tombol "Tambah" digunakan untuk input data pembagian air irigasi dan menghitung secara otomatis total realisasitanam, kebutuhan air irigasi dan pemberian air irigasi. Lihat Pada gambar 12. 


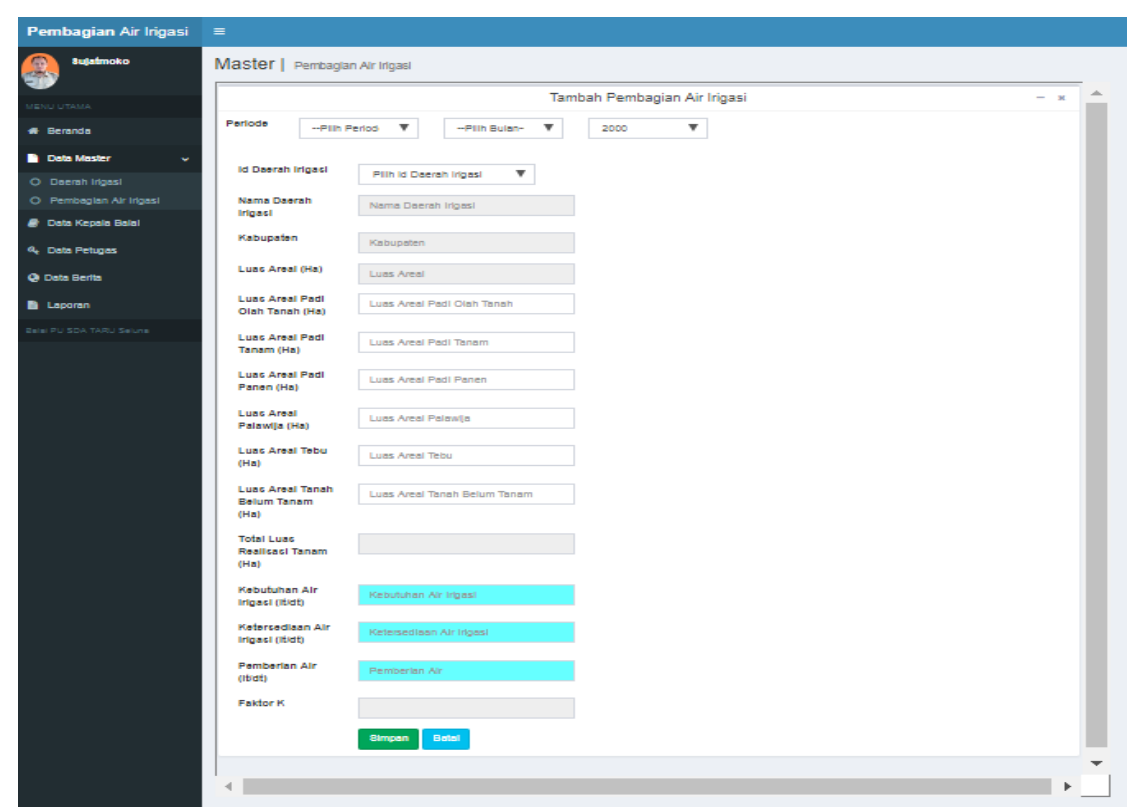

Gambar 12. Gambar Menu Input Pembagian Air Irigasi

Dengan menginputkan luas areal padi olah tanah, luas areal padi tanam, luas areal padi panen, luas areal palawija, luas areal tebu, luas areal tanah belum tanam, dan ketersediaan air irigasi maka secara otomatis sistem akan menghitung total realisasi tanam, kebutuhan air irigasi, pemberian air dan fakkor $\mathrm{K}$ sesuai rumus yang telah disetting pada sistem berdasarkan id daaerah irigasi yang dipilih.

c. Menu Laporan

Menu laporan digunakan untuk mencetak laporan pembagian air irigasi pada daerah irigasi sistem kedung ombo pada periode tertentu. Lihat pada gambar 13.

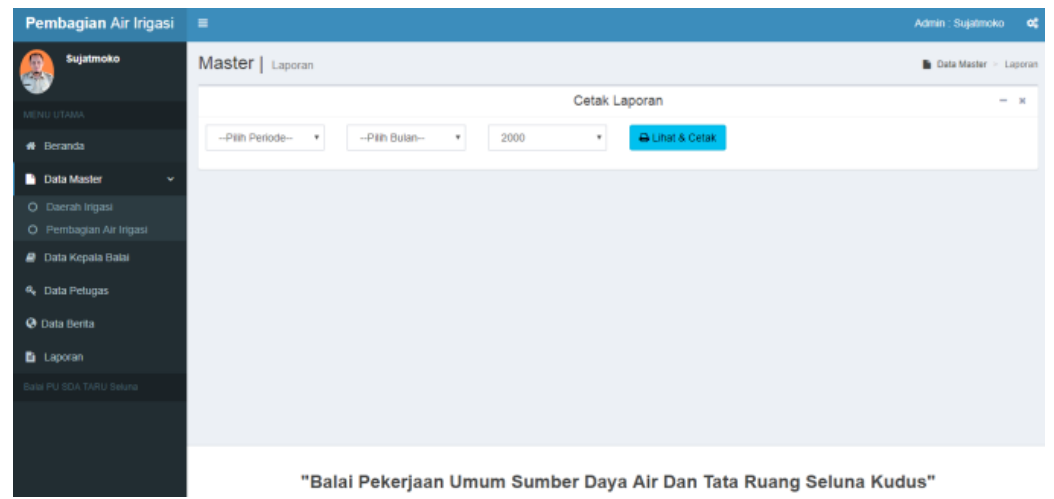

Gambar 13. Gambar Menu Laporan

Jika ingin mencetak laporan maka harus pilih periode, pilih bulan dan milih tahun pembagian air irigasi terlebih dahulu, sebagai contoh periode II bulan September tahun 2017, hasil cetak laporan bisa dilihat Pada gambar 14. 


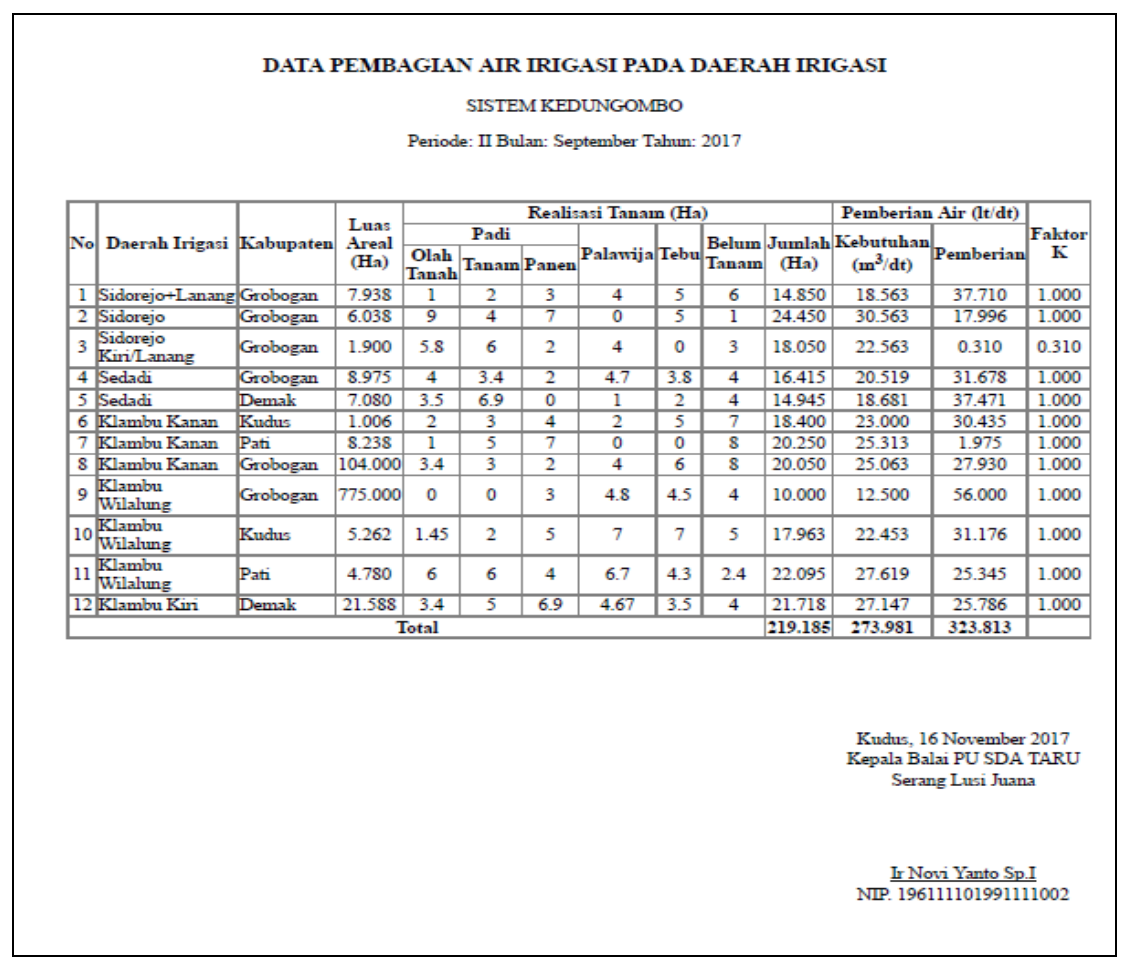

Gambar 14. Gambar Hasil Cetak Laporan

\subsubsection{Halaman Operator}

Pada halaman operator hanya terdapat menu data daerah irigasi, menu pembagaian air irigasi dan cetak laporan. Lihat pada gambar 15.

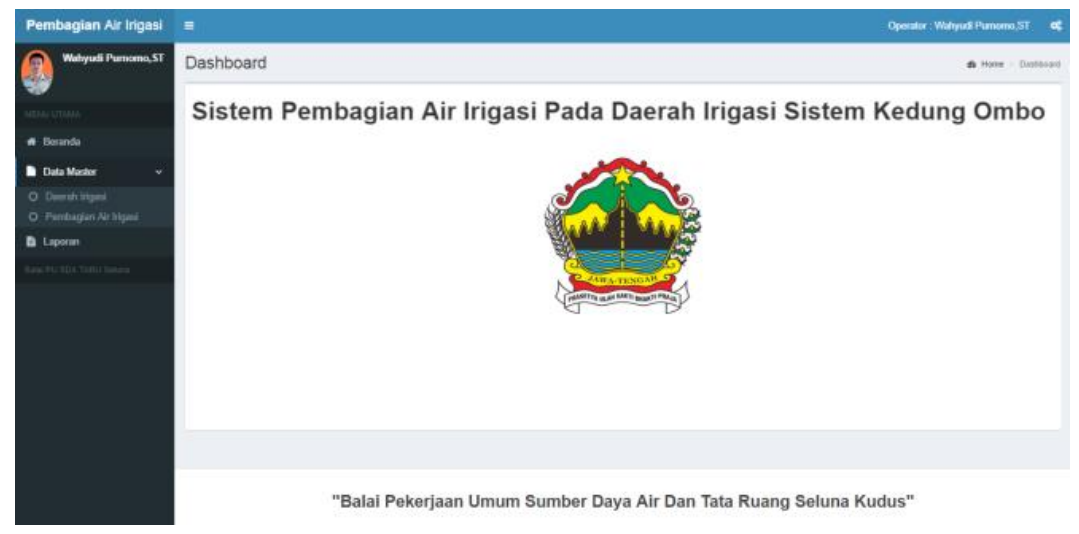

Gambar 15. Gambar Halaman Operator 


\section{KESIMPULAN DAN SARAN}

\subsection{Kesimpulan}

Dari pembahasan yang telah diuraikan, maka penulis dapat mengambil suatu kesimpulan dari perancangan aplikasi pembagian air irigasi pada daerah irigasi sistem kedung ombo. Adapun kesimpulannya antara lain:

a. Aplikasi yang dirancang dapat memberikan kemudahan bagi pihak Balai PU SDA TARU Seluna Kudus dalam proses perhitungan realisasi tanam, kebutuhan air irigasi dan pemberian air irigasi pada daerah irigasi sistem kedung ombo khususnya dibidang operasi dan pemeliharaan (OP).

b. Dengan adanya sistem penyimpanan data pembagian air irigasi dalam database maka akan mempermudah petugas dalam melakukan tugasnya tanpa adanya kesulitan dan memudahkan dalam melakukan percetakan laporan yang diperlukan sehingga prosesnya menjadi cepat.

\subsection{Saran}

Dari peninjauan dan riset dari permasalahan yang ada, maka penulis berkeinginan memberikan saran-saran yang mungkin dapat digunakan sebagai bahan pertimbangan bagi para pembaca yaitu sebagai berikut:

a. Aplikasi sistem pembagian air irigasi ini hanya mengolah data angka kebutuhan air irigasi, ketersediaan air irigasi dan pemberian air, belum adanya sistem yang mengatur buka tutup pintu pembagian air irigasi secara otomatis berdasarkan kebutuhan air irigasi.

b. Dalam mengatasi masalah kekurangan sistem, maka pengguna di anjurkan untuk memperbaruhi sebagian program aplikasi yang ada untuk melengkapi kelemahan dari program secara berkala.

c. Penulis berharap sistem ini dapat dikembangkan lagi mengenai perhitungan atau variabel yang memperhitungkan ketinggian permukaan waduk minimum dikarenakan pada studi kasus ini ketinggian permukaan waduk di abaikan.

\section{DAFTAR PUSTAKA}

[1] Abdul, R., (2004), "Sistem Pendukung Keputusan Untuk Perencanaan Dan Pengendalian Kebutuhan Air Irigasi Di Balai Pengairan Kediri”, Skripsi, Fakultas Teknik, STIKOM, Surabaya.

[2] Ali, dkk. 2013, Logika Dan Algoritma, Program Studi Teknik Informatika, Politeknik Elekronika Negeri Surabaya.

[3] Cynthia, dkk. (2011), "Tinjauan Faktor K Sebagai Pendukung Rencana Pembagian Air Irigasi Berbasis FPR", Jurnal Teknik Pengairan. Google Cendekia, http://scholar.google.ac.id, Program Studi Teknik Pengairan, Universitas Brawijaya

[4] Eka, dkk. (2007), "Evaluasi Kinerja Daerah Irigasi Jragung Kabupaten Demak”, Jurnal Teknik Pengairan. Google Cendekia, http://scholar.google.ac.id, Program Studi Teknik Pengairan, Universitas Brawijaya

[5] Fahriza, dkk. (2015), "Studi Optimasi Pola Pemberian Air pada Daerah Irigasi Tumpang”, Jurnal Teknik Pengairan. Google Cendekia, http://scholar.google.ac.id, Program Studi Teknik Pengairan, Universitas Brawijaya

[6] Ikosa Ardiyanto, (2007) "Evaluasi Pola Operasi Waduk di Sistem Kedung Ombo", Jurnal Teknik Pengairan. Google Cendekia, http://scholar.google.ac.id, Program Studi Teknik Sipil, Universitas Katolik Soegijapranata Semarang.

[7] Indra, dkk. (2014), “Analisa Ketersediaan Dan Kebutuhan Air Pada DAS Sampean”, Jurnal Teknik Pengairan. Google Cendekia, http://scholar.google.ac.id, Program Studi Teknik Pengairan, Universitas Brawijaya

Purwanto, dkk. (2016), "Analisis Kebutuhan Air Irigasi Air Irigasi Pada Daerah Irigasi Bendung Mrican 1", Jurnal Teknik Pengairan. Google Cendekia, http://scholar.google.ac.id, Program Studi Teknik Sipil, Universitas Muhammadiyah Yogyakarta 